\title{
적수온(21-24 $\left.{ }^{\circ} \mathrm{C}\right)$ 에서 사육한 성장기(317 g) 넙치(Paralichthys olivaceus)의 배합사료 적정 공급률
}

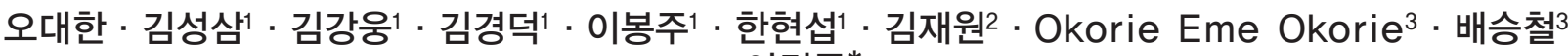 \\ - 이경준*
}

제주대학교 해양생명과학과, ${ }^{1}$ 국립수산과학원 사료연구센터, ${ }^{2}$ 강원도립대학교 해양생명과학과, ${ }^{3}$ 부경대학교 해양바이오신소재학과

\section{Optimum Feeding Rate for Growing Olive Flounder (317 g) Paralichthys olivaceus Fed Practical Extruded Pellets at Optimum Water Temperature $\left(21-24^{\circ} \mathrm{C}\right)$}

\author{
Dae-Han Oh, Sung-Sam Kim ${ }^{1}$, Kang-Woong Kim¹, Kyoung-Duck Kim¹, Bong-Joo Lee ${ }^{1}$, \\ Hyon-Sob Han ${ }^{1}$, Jae-Won Kim², Okorie Eme Okorie ${ }^{3}$, Sungchul C. Bai ${ }^{3}$ and Kyeong-Jun Lee* \\ Department of Marine Life Science, Jeju National University, Jeju 690-756, Korea \\ ${ }^{1}$ Aquafeed Research Center, National Fisheries Research and Development Institute, Pohang 791-923, Korea \\ ${ }^{2}$ Department of Marine Life-Science, Gangwon Provincial college, Gangneung 210-804, Korea \\ ${ }^{3}$ Department of Marine Bio-Materials, Pukyong National University, Busan 608-737, Korea
}

We investigated the effects of feeding rate on the growth performance, blood components, and histology of growing olive flounder Paralichthys olivaceus. Optimum feeding rate (initial fish mean weight : $316.7 \pm 6.18 \mathrm{~g}$ ) was determined under the optimum water temperature. Two replicated groups of fish were fed a commercial diet at rates of $0 \%, 0.4 \%, 0.6 \%$, and $0.8 \%$ of body weight (BW) per day, and to satiation. Feeding trial was conducted using a flow-through system with 101.2 -metric ton aquaria receiving filtered seawater at $21-24^{\circ} \mathrm{C}$ for 3 weeks. Weight gain (WG) and specific growth rate (SGR) were significantly higher in fish fed to satiation (1.0\% BW/day) than in those in other treatments. These parameters were negative and significantly lower in the starved fish than in fish fed the experimental diet at all feeding rates. There were no significant differences in WG and SGR among fish fed at $0.4 \%$, $0.6 \%$, and $0.8 \% \mathrm{BW} /$ day. Hematocrit and hemoglobin in fish fed to satiation were significantly lower than those in other treatments. Histological changes of fish fed at $0.6 \% \mathrm{BW} /$ day indicated that this group was in the best condition; differences were not found in tissues of fish fed at $0 \%, 0.6 \%$ and $1.0 \% \mathrm{BW} /$ day. Broken-line regression analysis of weight gain showed that the optimum feeding rate of olive flounder weighing $317 \mathrm{~g}$ was $0.99 \% \mathrm{BW}$ per day at the optimum water temperature.

Key words: Olive flounder, Feeding rate, Optimum water temperature, Histology, Hepatopancreas

\begin{abstract}
서 론
세계 양식선진국은 환경친화적 배합사료를 사용하여 지속가 능한 양식업을 육성하고 경쟁력을 강화하고 있다. 우리나라도

http://dx.doi.org/10.5657/KFAS.2014.0399

This is an Open Access article distributed under the terms of the Creative Commons Attribution Non-Commercial Licens (http://creativecommons.org/licenses/by-nc/3.0/)which permits unrestricted non-commercial use, distribution, and reproduction in any medium, provided the original work is properly cited.
\end{abstract}

안전한 양식수산물 공급, 수산자원 남획 및 어장환경오염 방지 등 지속가능한 양식업 육성을 위하여 배합사료 사용 확대가 필 요한 시점이다(Kim et al., 2014). 최근 우리나라의 경우 배합사 료 의무화 정책을 위해 제주, 신안, 여수, 울진, 영덕을 배합사료

\section{Kor J Fish Aquat Sci 47(4) 399-405, August 2014}

Received 25 July 2014 Revised 22 August 2014; Accepted 25 August 2014

*Corresponding author: Tel: +82. 64. 754.3423 Fax: +82. 64. 756.3493

E-mail address: kjlee@jejunu.ac.kr 
시범지역으로 선정하여 넙치, 돔류, 조피볼락, 강도다리 등 다 양한 어류를 대상으로 $100 \%$ 배합사료를 사용하여 양식하고 있 다. 따라서 향후 배합사료 사용확대를 위해서는 각 양식어종에 대한 배합사료 급여량 및 급여횟수에 대한 공급프로그램이 개 발되어야 할 것이다.

외국의 경우 주요 양식어종(채널메기, 잉어, 틸라피아, 송어) 을 대상으로 성장단계별 및 사육수온별로 배합사료 급여량 및 급여횟수에 대한 공급프로그램이 개발되었다(Schmittou et al., 1998; NRC, 2011). Schmittou et al. (1998)의 연구에 의하면 채 널메기, 잉어 및 틸라피아의 어체중에 따른 사료급여량 및 급여 횟수를 정리하였는데, 채널메기의 경우 $25-600 \mathrm{~g}$ 사이의 적정 공급률은 $4.0 \%$ 에서 $1.2 \%$, 공급횟수는 1 일 2 회 공급에서 $150 \mathrm{~g}$ 이후에는 1 일 1 회 공급으로 성장함에 따라 감소되는 결과를 보 였다. 잉어 및 틸라피아에서도 적정공급률은 $4.5 \%$ 에서 $1.4 \%$, 공급횟수는 1 일 3 회에서 1 일 2 회로 어류가 성장함에 따라 공급 률은 감소되는 결과를 보였다.

넙치는 2013년 기준 우리나라 전체 해산어 총생산량 73,108 톤 중 36,944 톤이 생산되어 $51 \%$ 를 차지하는 중요한 양식어종 이다(Statistics Korea, 2014). 자연환경에서 넙치의 서식수온은 $10-27^{\circ} \mathrm{C}$ 범위이며, 양식환경에서 적정사육수온은 $8-25^{\circ} \mathrm{C}$ 이지 만 $4-28^{\circ} \mathrm{C}$ 에서도 사육이 가능하며, 최적 사육수온은 $21-24^{\circ} \mathrm{C}$ 로서 수온 $10^{\circ} \mathrm{C}$ 이하와 $27^{\circ} \mathrm{C}$ 이상에서는 먹이섭취 활성이 현저 하게 떨어 진다(NFRDI, 2006). 아직까지 넙치를 대상으로 배 합사료의 사육수온별 및 성장단계별로 세부적인 공급프로그램 연구는 수행되지 않았다. 실제 넙치 양식현장에서는 공급프로 그램의 부재로 대부분 만복급여를 실시하고 있는 실정으로 성 장단계별 및 사육수온별로 적정공급률 조사를 통해 배합사료 공급프로그램을 개발이 필요하다. 본 연구는 배합사료 공급프 로그램 개발을 위한 기초연구로 $317 \mathrm{~g}$ 넙치의 최적 사육수온 범 위인 $21-24^{\circ} \mathrm{C}$ 수온에서 배합사료의 적정공급률 조사와 더불어 성장, 사료효율, 혈액성분 및 조직성상에 미치는 영향을 알아보 기 위해 수행되었다.

\section{재료 및 방법}

\section{실험사료}

본 실험에 사용된 실험사료는 상업용 시판 넙치용 배합사료 를 이용하였으며, 일반성분 분석은 Table 1에 나타내었다. 316 $\mathrm{g}$ 성장기 넙치의 적정 사료급여량 확인을 위해 어체 무게당 $(\mathrm{g})$ $0 \%, 0.4 \%, 0.6 \%, 0.8 \%$ 및 만복공급(saturation)으로 설정하여 총 5 개 실험구로 나누어 급여하였다. 실험 시작 전 공급률 설정 을 위해 실험어류를 대상으로 4일간 만복으로 실험사료를 공급 한 후 공급률을 설정하였다.

\section{실험어 및 사육관리}

사양실험에 사용된 실험어류는 제주도내 창해수산에서 제주
대학교 소속 해양과환경연구소로 운송되어 2 주 동안 시판 배합 사료를 급여하면서 실험환경에 적응할 수 있도록 순치시킨 후 사료공급실험에 사용되었다. 예비사육 후 실험어류(초기 평균 무게: $316.7 \pm 6.18 \mathrm{~g}$ )는 총 10 개의 $1,200 \mathrm{~L}$ 원형수조에 각 수조 당 20 마리씩 무작위로 선택하여 배치되었다. 사료공급실험은 실험구당 2 반복구를 두었으며, 사육수는 여과해수를 사용하여 2-3 L/min 의 유수량이 공급되도록 조절되었고, 모든 실험수조 에 용존산소 유지와 원활한 사육수 순환을 위하여 에어스톤을 설치하였다. 광주기는 자동타이머가 설치된 형광등을 이용하 여 12L:12D 조건으로 유지되었고, 전 실험기간 동안 평균 수온 은 $21^{\circ} \mathrm{C}$ 에서 $24^{\circ} \mathrm{C}$ 범위로 자연수온에 의존되었다. 실험사료는 1 일 2회 (오전 08:00, 오후 18:00)에 나눠서 3주 동안 어체중의 수준별로 급여 하였다.

\section{샘플수집}

사료공급 실험 후, 어류의 최종 평균무게를 측정하여 증체율 (Weight gain), 사료효율(Feed efficiency), 일간성장률(Specific growth rate), 단백질이용효율(Protein efficiency ratio) 및 생존율(Survival)을 계산하였다. 최종 무게측정 후, 혈액분석을 위해 각 수조마다 4마리씩 무작위로 선별하여 마취용액(MS$222,100 \mathrm{mg} / \mathrm{L}$ )으로 마취시켜 헤파린 처리가 된 주사기를 사 용하여 미부동맥에서 채혈한 후, Hematocrit 및 Hemoglobin 함량을 측정하였다. 분석 후, 남은 혈액은 ALT (alanine aminotransferase), AST (aspartate aminotransferase), Total protein 및 Glucose 분석을 위해 원심분리기(Micro 17TR, Hanil Science, Korea)를 이용하여 $5,000 \mathrm{rpm}$ 으로 10 분간 원심분리하여 혈장을 분리하였다.

\section{일반성분 분석}

실험사료의 일반성분 분석은 $\mathrm{AOAC}(2000)$ 방법에 따라 수분 은 상압가열건조법 $\left(125^{\circ} \mathrm{C}, 3 \mathrm{~h}\right)$, 조회분은 직접회화법 $\left(550^{\circ} \mathrm{C}\right.$, $12 \mathrm{~h})$ 으로 측정하였고, 단백질은 자동 조단백분석기(Kejltec system 2300, Sweden)로 분석되었으며, 지방은 Folch et al. (1959)의 방법에 따라 Soxhlet 추출장치(Soxhlet heater system C-SH6, Korea)를 이용하여 분석되었다.

Table 1. Proximate composition of the experimental diet for olive flounder Paralichthys olivaceus ( $\%$ of DM basis)

\begin{tabular}{lc}
\hline Proximate composition & Content \\
\hline Dry matter (\%) & 8.5 \\
Crude protein (\%, DM) & 56.5 \\
Crude lipid (\%, DM) & 14.6 \\
Crude ash (\%, DM) & 13.2 \\
Gross energy (MJ/kg) & 17.4 \\
Size $(\mathrm{mm})$ & $11.0-11.4$ \\
\hline
\end{tabular}




\section{혈액분석}

Hematocrit은 헤파린이 처리된 모세혈관채혈튜브(Micro Hematocrit Capillary Tubes)에 혈액을 채운 다음 고무판(Wax plates)에 세운 후, 혈액진단원심분리기(Micro Hematocrit VS12000 , Vision Scientific, Korea)에서 10분간 원심분리하여 값 을 측정하였다.

Hemoglobin, ALT, AST, Total protein 및 Glucose 함량은 각 각의 시약과 반응시킨 후 혈액생화학분석기(Express plus system, Bayer, USA)를 이용하여 분석하였다. ALT와 AST는 kinetic, Hemoglobin, Total protein 및 Glucose 함량은 end point 방법으로 분석되었다.

\section{조직학적 관찰}

넙치 해부를 통하여 간췌장, 신장 및 전장의 조직학적 변화를 확인하기 위해 각 실험구당 3 마리씩 무작위로 추출하였다. 해부 한 조직을 Bouin's solution에 24시간 동안 고정 후 고정된 샘플 을 수세와 탈수를 거쳐 paraffin에 포매하여 4-6 $\mu \mathrm{m}$ 두께로 연 속절편하여 조직표본을 만들었다. 제작된 조직표본은 Mayer's hematoxylin과 $0.5 \% \operatorname{eosin}(\mathrm{H}-\mathrm{E})$ 의 비교염색을 실시한 후 광학 현미경으로 관찰하였다.

\section{통계학적 분석}

실험사료군의 배치는 완전확률계획법(Completely randomized design)에 따라 실시하였고, 성장 및 분석결과는 SPSS (Version 12.0) 프로그램을 이용하여 One-way ANOVA로 통 계 분석되었다. 실험의 데이터 값의 유의차는 Duncan's multiple test $(P<0.05)$ 로 비교되었다. 데이터는 평균값 \pm 표준편차 $($ mean $\pm \mathrm{SD}$ )로 나타내었다. 백분율 데이터는 arcsine 변형 값
으로 계산하여 통계 분석되었다.

\section{결과 및 고찰}

성장기 넙치 $(317 \mathrm{~g})$ 를 대상으로 적수온기 배합사료 급여량을 알아보기 위한 3주간의 성장실험 결과는 Table 2에 나타내었 다. 성장결과에 있어서는 사료를 급여하지 않은 $0 \%$ 실험구에 서 어체중이 감소되는 성장률(-10.6\%)을 보였으며, 하루에 약 $0.66 \mathrm{~g}$ 어체중이 감소하였다. 증체율 및 일간성장률에서는 사 료급여량이 증가함에 따라 증가하여 만복실험구에서 유의적으 로 가장 높은 성장률을 보였다. 가장 성장률이 높은 만복실험구 의 경우 3주동안 약 $90 \mathrm{~g}$ 성장하였다. 사료효율, 단백질이용효 율 및 생존율에서는 유의적인 차이를 보이지 않았다. Kim et al. (2014)은 넙치 $(240 \mathrm{~g})$ 를 대상으로 $19-21{ }^{\circ} \mathrm{C}$ 수온에서 배합사료 공급률 $(0 \%, 0.5 \%, 0.75 \%, 1.0 \%$ 및 만복공급)을 조사한 결과, 사료를 공급하지 않은 절식실험구 $(0 \%)$ 에서 본 연구 결과와 유 사하게 어체중이 감소하는 성장률(-8.1\%)을 보였고 하루에 어 체중은 약 $0.40 \mathrm{~g}$ 감소하였다고 보고하였다. 증체율 및 일간성 장률에서는 만복실험구에서 가장 높았으나 $1.0 \%$ 실험구와 유 의적인 차이를 보이지 않았다. 이와 비슷하게 Kim et al. (2012) 은 넙치 $(140 \mathrm{~g})$ 를 대상으로 $20-23^{\circ} \mathrm{C}$ 수온에서 $350 \mathrm{~g}$ 까지 사육 한 결과 만복의 $90 \%$ 로 제한 공급한 실험구가 만복으로 공급한 실험구와 비교하여 높은 성장을 보였다. 조피볼락의 경우에도 만복의 $80 \%$ 사료공급이 적정 급여량으로 보고 되었으며(Lee, 1997), 잉어 역시 만복의 $88 \%$ 를 급여한 실험구가 만복급여 실 험구와 비교하여 유의적인 차이가 없다고 보고하였다(Cho et al., 2001). 하지만 본 연구에서는 만복실험구가 다른 실험구보 다 유의적으로 높은 성장률을 보인 것은 어종과 어류의 크기( 성장단계), 수온, 사료조성 등의 차이(Lee et al., 2000)로 판단

Table 2. Effects of feeding rate on the growth performance of olive flounder Paralichthys olivaceus fed the experimental diet for 3 weeks ${ }^{1}$

\begin{tabular}{|c|c|c|c|c|c|c|}
\hline & \multicolumn{5}{|c|}{ Diets } & \multirow{2}{*}{ Pooled SEM ${ }^{\top}$} \\
\hline & $0 \%$ & $0.4 \%$ & $0.6 \%$ & $0.8 \%$ & $\mathrm{~S}^{2}$ & \\
\hline Initial weight (g/fish) & 316.7 & 318.9 & 322.9 & 306.4 & 318.6 & 2.52 \\
\hline Final weight (g/fish) & $279.5^{\mathrm{a}}$ & $348.6^{b}$ & $377.5^{b}$ & $355.0^{\mathrm{b}}$ & $409.0^{c}$ & 14.53 \\
\hline Weight gain ${ }^{3}$ & $-10.6^{a}$ & $9.3^{b}$ & $16.9^{b}$ & $15.9^{b}$ & $28.4^{c}$ & 4.37 \\
\hline Specific growth rate ${ }^{4}$ & $-0.66^{a}$ & $0.52^{b}$ & $0.91^{\mathrm{b}}$ & $0.87^{b}$ & $1.47^{c}$ & 0.24 \\
\hline Feed efficiency ${ }^{5}$ & - & 112.6 & 131.6 & 104.8 & 128.6 & 8.76 \\
\hline Protein efficiency ratio 6 & - & 2.13 & 2.48 & 1.98 & 2.43 & 0.17 \\
\hline Survival (\%) & 85.7 & 82.1 & 85.7 & 85.7 & 82.1 & 1.06 \\
\hline
\end{tabular}

${ }^{1}$ Values are means from duplicate groups of fish; values in each row with different superscripts are significantly different $(P<0.05)$.

${ }^{2} \mathrm{~S}=$ Satiation $(1.0 \%)$.

${ }^{3}$ Weight gain $(\%)=($ final weight - initial weight $) \times 100 /$ initial weight.

${ }^{4}$ Specific growth rate $(\%)=\left(\log _{\mathrm{e}}\right.$ final wt. $-\log _{\mathrm{e}}$ initial wt. $) /$ days.

${ }^{5}$ Feed efficiency $(\%)=$ wet weight gain $(\mathrm{g}) \times 100 /$ dry feed intake $(\mathrm{g})$.

${ }^{6}$ Protein efficiency ratio $=$ wet weight gain $/$ protein intake .

${ }^{7}$ Pooled standard error of means: $\mathrm{SD} / \sqrt{ } \mathrm{n}$. 
되며, 향후 성장단계별로 보다 세밀한 연구가 수행되어져야 할 것으로 판단된다. 따라서 성장기 넙치 $317-409 \mathrm{~g}$ 넙치는 사료 섭취가 가능한 범위에서 사료가 허실되지 않게 최대한 만복으 로 급여하는 것이 성장에 도움이 될 것으로 판단된다. 본 실험 에서 사료공급량과 사료섭취율을 계산하였을 때 만복공급률은 $1.0 \%$ 로 분석되었다.

배합사료 급여량이 넙치의 혈액성상에 미치는 영향을 알아보 기 위해 조사한 혈액분석 결과는 Table 3에 나타내었다. AST 및 Glucose 함량에 있어서는 모든 실험구에서 유의적인 차이를 보 이지 않았다. 하지만 Hematocrit 및 Hemoglobin 수치는 만복 실험구가 다른실험구와 비교하여 유의적으로 낮은 결과를 보 였다. 본 연구는 비록 3 주라는 짧은 기간 동안 수행되었지만 만 복실험구에서 유의적으로 낮은 Hematocrit 및 Hemoglobin 수 치는 어류의 건강도에 악영향을 끼칠 수 있음을 의미한다. ALT 결과에서는 절식실험구 $(0 \%)$ 에서 유의적으로 높은 결과를 보 였다. Kim et al. (2011)은 넙치 치어를 대상으로 저수온 및 고 수온에서 사료급여량을 달리 하였을 때 Glutamic oxaloacetic transaminase (GOP) 수치를 분석한 결과, 저수온기에는 절식 실험구 및 $1.5 \%$ 실험구에서 $2.0 \%, 2.25 \%, 2.5 \%$ 및 만복실험 구 보다 유의적으로 높은 결과를 보였으며, 만복실험구로 사료 급여량이 증가함에 따라 $\mathrm{GOT}$ 수치가 감소하는 경향을 보였다. 고수온기에서도 저수온기와 비슷하게 사료공급율 $(0 \%, 3.0 \%$, $3.5 \%, 4.0 \%, 4.25 \%, 4.5 \%, 4.75 \%$ 및 만복공급)이 증가함에 따 라 $\mathrm{GOP}$ 수치가 감소하는 경향을 보였으며, 절식실험구 $(0 \%)$ 가 사료공급실험구와 비교하여 유의적으로 높은 결과를 보였다. $\mathrm{ALT}$ 와 AST는 일반적으로 척추동물에서 간의 기능과 상태를 나타내는 지표로서 사용되며 일반적으로 높은 ALT와 AST는 간 기능의 손상 또는 약화를 의미한다(Pan et al., 2003). 본 연구 에서 절식실험구 $(0 \%)$ 의 ALT 수치가 유의적으로 높은 것은 사 료를 섭취하지 못해 정상적인 영양소 대사가 이루어 지지 않았 기 때문으로 판단된다. 혈장에서 Total protein을 분석한 결과,
$0.8 \%$ 실험구가 $0.4 \%$ 실험구 보다 유의적으로 가장 높은 값을 보였으며, 다른 실험구와는 유의적인 차이를 보이지 않았다. 일 반적으로 어류에서 실험사료가 만복으로 충분히 공급되었을 경 우 혈장 내 Total protein 값은 차이를 보이지 않는다. Kim et al. (2009)은 자주복을 대상으로 단백질함량(35-55\%)을 달리하여 만복으로 급여하였을 때 모든 실험구의 혈장 내 Total protein 값 의 차이가 없었다. 따라서 $0.4 \%$ 실험구가 Total protein 값이 낮 게 나온 것은 사료량이 충분히 공급되지 않은 결과로 판단된다. 이와 비슷하게 사료량이 충분히 공급되지 않은 절식실험구에서 차이를 보이지 않은 것은 실험어류가 사료를 섭취하지 못해 정 상적인 영양소대사가 이루어 지지 않았기 때문으로 판단된다. Kim et al., (2014)은 $240 \mathrm{~g}$ 넙치를 대상으로 공급률 $(0 \%, 0.5 \%$, $0.75 \%, 1.0 \%$ 및 만복공급)을 달리하여 실험한 결과, 절식실험 구에서 높은 Total protein 수치를 보였으며, 본 연구결과와 유 사하게 가장 낮은 공급량인 $0.5 \%$ 실험구에서 유의적으로 낮은 Total protein 수치를 보였다. 이상의 혈액결과를 종합해 보면, 만복급여는 혈액 내 Hematocrit 및 Hemoglobin 수치를 감소시 키고, 절식실험구 $(0 \%)$ 는 ALT 수치가 증가되어 어류의 건강도 에 좋지 않은 영향을 끼치는 것을 알 수 있었다. 보다 더 정확한 매커니즘을 파악하기 위해서는 장기간 사육실험을 통한 평가가 이루어져야 할 것으로 판단된다.

사료급여량을 달리하여 사육한 실험어의 전어체 분석 결과 는 Table 4에 나타내었다. 전어체의 수분함량에서는 모든 실험 구에서 유의적인 차이를 보이지 않았다. 단백질 함량은 $0.8 \%$ 및 만복실험구에서 유의적으로 낮은 값을 보였으며, $0.6 \%$ 실 험구에서 유의적으로 높은 값을 보였다. 지방함량은 $0.8 \%$ 실 험구에서 유의적으로 가장 높은 값을 보였으며, $0.6 \%$ 실험구 에서 유의적으로 가장 낮은 값을 보였다. 회분함량은 만복실험 구에서 유의적으로 가장 높은 값을 보였으며, 절식실험구에서 유의적으로 가장 낮은 값을 보였다. 일반적으로 영양소의 함량 이 다른 배합사료를 공급하게 되면 전어체의 일반성분에 영향

Table 3. Effects of feeding rate on the serological characteristics of olive flounder Paralichthys olivaceus fed the experimental diet for 3 weeks ${ }^{1}$

\begin{tabular}{llllllc}
\hline & \multicolumn{5}{c}{ Diets } & \multirow{2}{*}{ Pooled SEM $^{5}$} \\
\cline { 2 - 6 } & $0 \%$ & $0.4 \%$ & $0.6 \%$ & $0.8 \%$ & $\mathrm{~S}^{2}$ & 0.60 \\
\hline Hematocrit (\%) & $23.5^{\mathrm{b}}$ & $25.4^{\mathrm{b}}$ & $23.8^{\mathrm{b}}$ & $25.6^{\mathrm{b}}$ & $22.1^{\mathrm{a}}$ & 0.48 \\
Hemoglobin $(\mathrm{g} / \mathrm{dL})$ & $6.63^{\mathrm{b}}$ & $6.17^{\mathrm{b}}$ & $6.36^{\mathrm{b}}$ & $7.49^{\mathrm{b}}$ & $3.53^{\mathrm{a}}$ & 2.79 \\
AST $(\mathrm{U} / \mathrm{L})^{3}$ & 22.5 & 25.3 & 27.8 & 28.9 & 13.1 & 9.18 \\
ALT $(\mathrm{U} / \mathrm{L})^{4}$ & $69.5^{\mathrm{b}}$ & $22.8^{\mathrm{ab}}$ & $17.4^{\mathrm{ab}}$ & $7.0^{\mathrm{a}}$ & $11.5^{\mathrm{ab}}$ & 2.88 \\
Glucose $(\mathrm{mg} / \mathrm{dL})$ & 14.8 & 25.7 & 19.5 & 10.6 & 19.1 & 0.34 \\
Total protein $(\mathrm{mg} / \mathrm{dL})$ & $2.94^{\mathrm{ab}}$ & $2.06^{\mathrm{a}}$ & $3.04^{\mathrm{ab}}$ & $4.80^{\mathrm{b}}$ & $3.59^{\mathrm{ab}}$ & \\
\hline
\end{tabular}

${ }^{1}$ Values are means from duplicate groups of fish; values in each row with different superscripts are significantly different $(P<0.05)$. ${ }^{2} \mathrm{~S}=$ Satiation $(1.0 \%)$.

${ }^{3} \mathrm{AST}=$ Aspartate aminotransferase, Unit per liter $(\mathrm{U} / \mathrm{L})$ is the amount of enzyme which oxidizes one $\mu \mathrm{mol} / \mathrm{L}$ of NADH per minute. ${ }^{4} \mathrm{ALT}=$ Alanine aminotransferase.

${ }^{5}$ Pooled standard error of means: $\mathrm{SD} / \sqrt{ } \mathrm{n}$. 
을 미친다. Kim et al. (2009)은 단백질함량(35-55\%)을 달리하 여 공급한 결과 사료 내 단백질함량이 $50 \%$ 까지 증가할수록 전 어체의 단백질 함량이 증가하였으며, $55 \%$ 에서는 더 이상 증가 하지 않았다. 지방함량에 있어서는 사료 내 단백질함량이 가장 낮은 $35 \%$ 에서 낮은 지방함량을 보였다. 다른 어종을 대상으로 연구한 결과에서도 이와 비슷한 연구결과를 보였다(Kim et al., 2001; Lee et al., 2001; Kim et al., 2002). 본 연구에서는 동일한 실험사료를 공급하였음에도 불구하고 전어체의 일반성분 결과 가 다른 것은 급여량을 제한함으로써 어체성장에 필요한 적정 영양소요구량을 섭취하지 못하였기 때문으로 판단된다. 따라 서 배합사료의 급여량이 과잉 또는 부족하게 되어 전어체의 일 반성분에도 영향을 주었을 것으로 판단된다. 하지만 보다 더 정 확한 매커니즘을 파악하기 위해서는 장기간의 실험을 통한 증 명이 필요할 것으로 판단된다.

배합사료의 급여량이 넙치의 간췌장, 신장 및 전장의 조직 학적 변화에 미치는 영향을 알아보기 위해 $0 \%$ (절식실험구), $0.6 \%$ 및 만복실험구 $(1.0 \%)$ 의 조직상을 조사한 결과는 Fig. 1 에 나타내었다. 3 주간의 사육실험 동안 모든 실험구에서 복부팽창 과 같은 병변현상은 관찰되지 않았다. 3 개 실험구의 간췌장에 서는 모두 간세포가 응축되고 모세혈관의 팽창 및 췌장 효소원 과립들이 감소된 상태로서 미약한 병변현상을 나타내었다(Fig. $1 \mathrm{~A}-\mathrm{C})$. 신장은 절식실험구, $0.6 \%$ 실험구 및 만복공급구 모두 사구체 내 혈구세포가 팽창하고, 흑색 대식세포들이 관찰되었 고, 신관 상피층 상피세포의 팽창이 미약하게 관찰되었다(Fig. $1 \mathrm{D}-\mathrm{F})$. 전장은 $0.6 \%$ 실험구에서는 정상적인 조직상을 보였으 나 절식실험구와 만복공급구에서 점막상피층 핵들이 응축되는 형태를 보였다(Fig. 1G-I). 이와 비슷하게 Kim et al. (2011)은 저수온기 넙치 치어를 대상으로 배합사료 급여량을 달리하여 간췌장, 신장, 전장에서 조직분석을 실시한 결과, 적정급여량 실험구가 절식실험구 및 만복실험구와 비교하여 양호한 조직 상을 보여 주었다. Kim et al., (2014) 연구에서도 적정수온에 서 넙치 $240 \mathrm{~g}$ 을 대상으로 급여량을 달리하여 조직분석을 실시 한 결과, 적정급여량 실험구가 절식실험구 및 만복실험구와 비 교하여 양호한 조직상을 보여 주었다. 이러한 결과는 어류가 사
료를 정상적으로 섭취하지 못하거나 이와 반대로 과잉 공급되 어 영양소의 소화 및 흡수 작용에 영향을 미친 것으로 사료된다. 성장률을 기초로 Broken-line 분석을 통해 배합사료의 적정 공급률을 분석한 결과, 어체중 당 $0.99 \%$ 로 분석되었다(Fig. 2). 본 연구와 비슷한 수온에서 지금까지 연구 보고된 넙치의 배합 사료 급여량 연구결과를 살펴보면, Choi et al. (2008)은 $13 \mathrm{~g}$ 넙 치치어를 대상으로 여름철 평균수온이 $21-25^{\circ} \mathrm{C}$ 일때 실험한 결 과 어체중 당 $3.56 \%$ 가 적정 공급률로 보고되었으며, Kim et al. (2014)은 적수온 $\left(19-21^{\circ} \mathrm{C}\right)$ 에서 $240 \mathrm{~g}$ 넙치를 대상으로 실험한 결과 적정 공급률이 어체중 당 $1.09 \%$ 라고 보고하였다. 이와 반 대로 수온이 낮은 겨울철에 수행된 배합사료 공급률 연구결과 를 살펴보면, 넙치 $(281 \mathrm{~g})$ 를 대상으로 $12^{\circ} \mathrm{C}$ 에서 적정공급률은 어체중 당 $0.32 \%$ (Kim et al., 2009), $13^{\circ} \mathrm{C}$ 수온에서 $117 \mathrm{~g}$ 넙 치의 적정공급률은 어체중 당 1 일 1 회 만복으로 급여하는 것을 추천하였으며, 급여량은 어체중 당 $0.3 \%$ 로 보고되었다(Kim et al., 2010). 이와 같이 넙치에 있어서 수온별 및 성장단계별로 배합사료공급률은 큰 차이를 보이지만 이에 대한 연구는 턱 없 이 부족한 현실이다. 과거 넙치양식은 $1 \mathrm{~kg}$ 까지 키우면 상품크 기가 되었으나, 현재는 2-3 kg까지 키우고 있는 실정이다. 따라 서 향후 성장단계 및 사육수온을 보다 세부적으로 나누어 대형 크기의 넙치에 대한 적정공급률 연구가 반드시 수행되어야 할 것이다.

연구결과를 종합해 보면, 배합사료의 공급률은 성장기 넙치 (317-409 g)의 성장, 혈액학적 및 조직학적 변화에 영향을 끼 칠 수 있을 것으로 판단된다. 따라서 넙치 사육시 사육수온과 성 장단계를 고려하여 사료가 과잉 또는 부족하게 공급되지 않도 록 주의하여야 할 것이다. 또한 성장단계에 따라 다르지만, 성 장기 넙치 $(317 \mathrm{~g})$ 단계에서 장기간 사료를 급여하지 않거나 만 복공급을 했을 경우 어류의 건강도에 악영향을 끼칠 수 있을 것 으로 판단된다. 최적수온인 $21-24^{\circ} \mathrm{C}$ 에서 성장기 넙치(317-409 $\mathrm{g}$ )는 성장을 위해서는 만복으로 배합사료를 급여하는 것을 추 천하며, 배합사료 공급률은 어체중 당 $0.99 \%$ 가 적절한 것으로 사료된다. 향후에는 장기간에 걸쳐 치어부터 성어까지 전체 성 장단계에 대한 절식 및 만복급여에 대한 효과가 평가되어야 할

Table 4. Effects of feeding rate on the whole-body composition of olive flounder Paralichthys olivaceus fed the experimental diet for 3 weeks $(\%)^{1}$

\begin{tabular}{llllllc}
\hline & \multicolumn{5}{c}{ Diets } & \multirow{2}{*}{ Pooled SEM $^{3}$} \\
\cline { 2 - 6 } & $0 \%$ & $0.4 \%$ & $0.6 \%$ & $0.8 \%$ & $S^{2}$ & 0.43 \\
Moisture & 72.0 & 73.7 & 74.3 & 71.7 & 72.1 & 0.57 \\
Crude protein & $68.2^{\mathrm{b}}$ & $68.1^{\mathrm{b}}$ & $70.3^{\mathrm{c}}$ & $65.4^{\mathrm{a}}$ & $66.6^{\mathrm{a}}$ & 0.74 \\
Crude lipid & $20.7^{\mathrm{c}}$ & $20.9^{\mathrm{c}}$ & $15.9^{\mathrm{a}}$ & $22.6^{\mathrm{d}}$ & $19.6^{\mathrm{b}}$ & 0.53 \\
Crude ash & $9.9^{\mathrm{a}}$ & $11.2^{\mathrm{ab}}$ & $13.3^{\mathrm{c}}$ & $11.9^{\mathrm{b}}$ & $14.2^{\mathrm{c}}$ & $0.50 .05)$. \\
\hline
\end{tabular}

${ }^{1}$ Values are means from duplicate groups of fish; values in each row with different superscripts are significantly different $(P<0.05)$.

${ }^{2} \mathrm{~S}=$ Satiation $(1.0 \%)$.

${ }^{3}$ Pooled standard error of means: $\mathrm{SD} / \sqrt{ }_{\mathrm{n}}$. 


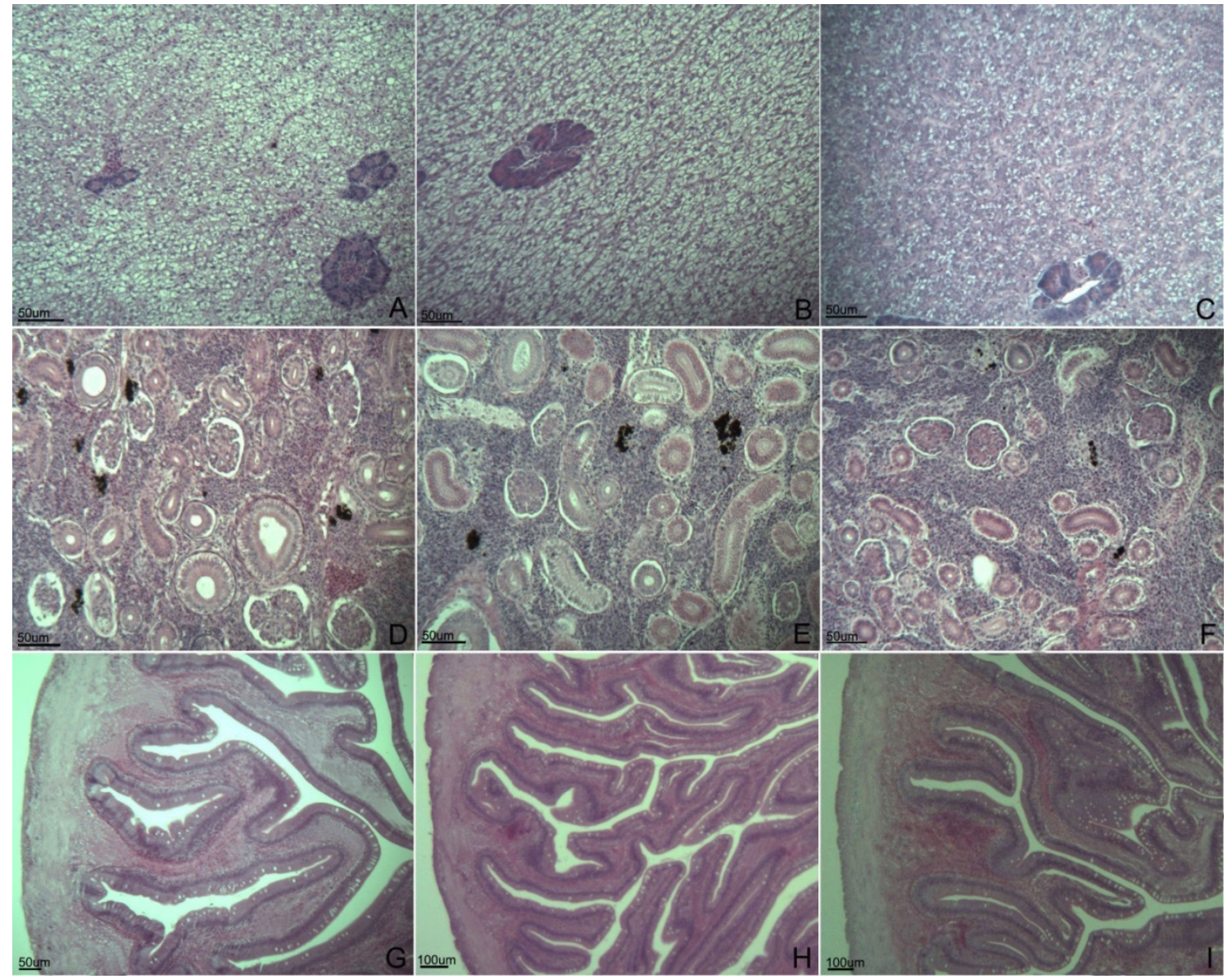

Fig. 1. Histological changes of the hepatopancreas, kidney and anterior intestine of olive flounder Paralichthys olivaceus fed the experimental diet for 3 weeks. A, D and G: 0\% group (A: hepatopancreas, D: kidney, and G: anterior intestine); B, E and H: 0.6\% group (B: hepatopancreas, E: kidney, and H: anterior intestine); C, F and I: S (satiation, 1.0\%) group (C: hepatopancreas, F: kidney, and I: anterior intestine).

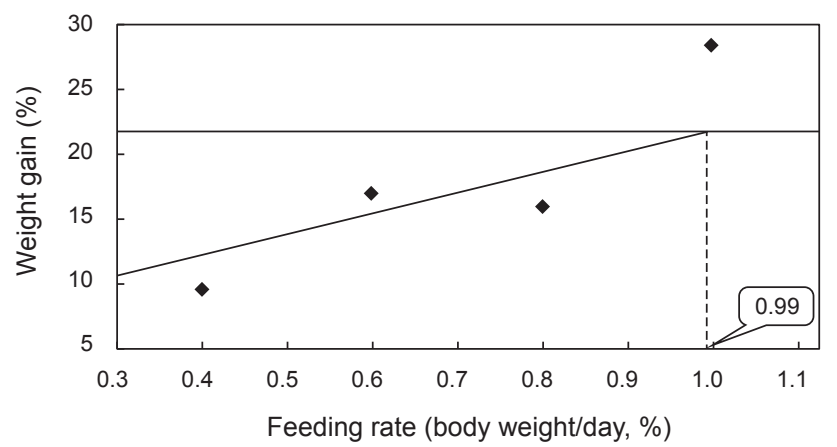

Fig. 2. Broken-line regression analysis of weight gain (\%) according to feeding rate. Each point represents the average of two groups of fish. The optimum feeding rate for weight gain was $0.99 \%$ body weight/day.

\section{것으로 판단된다.}

\section{사 사}

이 논문은 2014년도 제주대학교 학술진흥연구비 지원사업에 의하여 연구되었으며, 이에 감사드립니다.

\section{References}

AOAC (Association of Official Analytical Chemists). 2000. Official Methods of Analysis of the Association of Official Analytical Chemists, 17th Edition. Cunniff P, ed. Association of Official Analytical Chemists, Inc, Arlington, VA, U.S.A.

Cho SH, Jo JY and Kim DS. 2001. Effects of variable feed allowance with constant energy and ratio of energy to protein in a diet for constant protein input on the growth of common carp Cyprinus carpio L. Aquacult Res 32, 349-356.

Choi SM, Kim KW, Kang YJ, Park HS and Bai SC. 2008. Optimum dietary lipid level and feeding rates of extruded pellets in juvenile flounder Paralichthys olivaceus during the 
summer season. J Auqaculture 21, 244-251. http://dx.doi. org/10.1016/j.aquaculture.2005.05.041.

Folch J, Lee M and Sloane-Stanley GH. 1959. A simple method for the isolation and purification of total lipids from animal tissues. J Biol Chem 226, 497-509.

Kim KD, Nam MM, Kim KW, Kim DG and Son MH. 2010. Effects of feeding rate and frequently on the winter growth and body composition of olive flounder, Paralichthys olivaceus. Kor J Fish Aquat Sci 43, 217-222.

Kim KD, Nam MM, Kim KW, Lee HY, Hur SB, Kang YJ and Son MH. 2009. Effects of feeding rate and feeding frequency on growth and body composition of sub-adult flounder Paralichthys olivaceus in suboptimal water temperature. Kor J Fish Aquat Sci 42, 262-267.

Kim KD, Kim KW, Bae KM, Son MH and An CM. 2012. Effects of different numbers of feedineg days and feeding rate on growth of growing-out Flounder Paralichthys olivaceus. Kor J Fish Aquat Sci 45, 523-526. http://dx.doi.org/10.5657/ KFAS.2012.0523.

Kim KW, Kim SS, Kim JW, Son MH, Kim KD, Bai SC and Lee KJ. 2011. Effect of feeding rate and pellet water-soaking on growth, blood components, and histology of olive flounder Paralichthys olivaceus. Kor J Fish Aquat Sci 44, 490-498.

Kim KW, Wang XJ and Bai SC. 2001. Reevaluation of the optimum dietary protein level for the maximum growth of juvenile Korean rockfish, Sebastes schlegeli (Hilgendorf). Aquac Res 32, 119-125.

Kim KW, Wang XJ and Bai SC. 2002. Optimum dietary protein level for maximum growth of juvenile olive flounder Paralichthys olivaceus (Temminck et Schlegel). Aquac Res 33, 673-679.

Kim KW, Hwang NY, Son MH, Kim KD, Lee JH, Liu Y, Yun YH, Park GH, Kim SS, Lee KJ and Bai SC. 2011. Optimum feeding rates in juvenile olive flounder Paralichthys olivaceus fed practical expanded pellet at low and high water temperatures. Kor J Fish Aquat Sci 44, 345-351.

Kim SS, Kim KW, Kim KD, Lee BJ, Han HS, Kim JW, Bai SC and Lee KJ. 2014. Optimum feeding rate in growing olive flounder Paralichthys olivaceus fed practical extruded pellet at optimum water temperature $\left(21^{\circ} \mathrm{C}\right)$. Jour Fish Mar Sci Edu 26, 787-795.

Kim SS, Kim KW, Kim KD, Lee BJ, Lee JH, Han HS, Kim JW and Lee KJ. 2014. Comparison of extruded and moist pellets for growth performance, water quality and histology of olive flounder Paralichthys olivaceus in Jeju fish farm. Jour Fish Mar Sci Edu 26, 667-675. http://dx.doi.org/10.13000/ JFMSE.2014.26.3.667.

Kim SS and Lee KJ. 2009. Dietary protein requirement of juvenile tiger puffer (Takifugu rubripes). Aquaculture 287, 219-222.

Lee JH, Kim SS, Kim KW, Kim KD, Lee BJ, Lee JH, Han HS, Kim JW, Kim SY and Lee KJ. 2014. Optimum feeding rate in growing olive flounder Paralichthys olivaceus fed practical expanded pellet at optimum water temperature. Kor J Fish Aquat Sci 47, 234-240. http://dx.doi.org/10.5657/ KFAS.2014.0234.

Lee SM. 1997. Effects of feeding rates on growth, feed efficiency and body composition of the juvenile Korean rockfish (Sebastes schlegeli). Kor J Anim Nutr Feed 21, 327-334.

Lee SM, Cho SH and Kim DJ. 2000. Effects of feeding frequency and dietary energy level on growth and body composition of juvenile flounder, Paralicthys olivaceus (Temminck \&Schlegel). Aquac Res 31, 917-921.

Lee SM, Kim KD, Park HG, Kim CH and Hong KE. 2001. Protein requirement of juvenile Manchurian trout Brachymystax lenok. Fish Sci 67, 46-51. http://dx.doi.org/10.1046/ j.1444-2906.2001.00197.x.

NRC (Nutrient Research Council). 2011. Nutrient requirements of fish and shrimp. The National Academy Press, Washington DC, U.S.A., 279.

NFRDI (National Fisheries Research and Development Institute). 2009. Standard manual of olive flounder culture. NFRDI, Busan, Korea, 5.

Pan CH, Chien YH and Hunter B. 2003. The resistance to ammonia stress of Penaeus monodon Fabricius juvenile fed diets supplemented with astaxanthin. J Exp Mar Biol Ecol 297, 107-118. http://dx.doi.org/10.1016/j.jembe.2003.07.002.

Schmittou RH, Jian Z and Cramber MC. 1998. Principles and practices of 80:20 pond fish farming. American Soybean Association, St. Louis, U.S.A., 1-93.

Statistics Korea. 2014. Statistic Database for Aquaculture production. Retrieved from http://kostat.go.kr on July 02 . 